\title{
Effect of microporosity on nitrogen-doped microporous carbons for electrode of supercapacitor
}

\author{
Eun-A Cho, Seul-Yi Lee and Soo-Jin Park* \\ Department of Chemistry, Inha University, Incheon 402-751, Korea
}

\section{Article Info}

Received 21 March 2014

Accepted 12 May 2014

*Corresponding Author

E-mail: sjpark@inha.ac.kr

Tel: $+82-32-876-7234$

\section{Open Access}

DOI: http://dx.doi.org/

10.5714/CL.2014.15.3.210

This is an Open Access article distributed under the terms of the Creative Commons Attribution Non-Commercial License (http://creativecommons.org/licenses/ by-nc/3.0/) which permits unrestricted non-commercial use, distribution, and reproduction in any medium, provided the original work is properly cited.

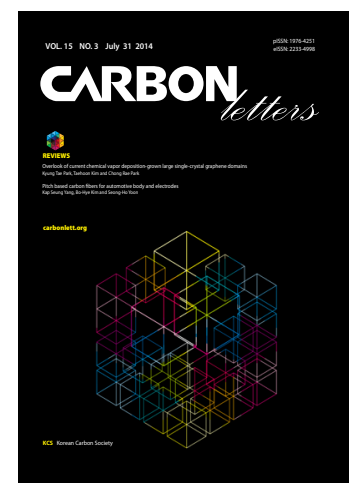

http://carbonlett.org

pISSN: $1976-4251$

elSSN: 2233-4998

Copyright $\odot$ Korean Carbon Society

\begin{abstract}
Nitrogen-doped microporous carbons were prepared using a polyvinylidene fluoride/ melamine mixture. The electrochemical performance of the nitrogen-doped microporous carbons after being subjected to different carbonization conditions was investigated. The nitrogen to carbon ratio and specific surface area decreased with an increase in the carbonization temperature. However, the maximum specific capacitance of $208 \mathrm{~F} / \mathrm{g}$ was obtained at a carbonization temperature of $800^{\circ} \mathrm{C}$ because it produced the highest microporosity.
\end{abstract}

Key words: supercapacitor, carbon electrode, carbonization temperature

\section{Introduction}

Supercapacitors are used for energy storage in various portable electronic devices and hybrid electric vehicles. They possess higher power and energy density, longer cycle life, and higher chemical stability compared to secondary batteries [1-3]. Recently, various carbonbased electrodes have been employed in supercapacitors because of their good electrical conductivity and large pseudocapacitance; however, they exhibit low capacitance values [4-6]. To improve their capacitance, nitrogen-containing functional groups are incorporated into the carbon materials. The pseudocapacitance originates from the interaction between the nitrogen species and protons of the electrolyte [7-10].

Recent studies have revealed that mesopores and macropores in capacitor electrodes have limited capacitance [11,12]. The presence of narrow micropores is essential for the formation of an electrical double layer by solvated and desolvated ions. According to the literature, pore sizes ranging from $0.7-1.2 \mathrm{~nm}$ produce the optimum specific capacitance in aqueous electrolytes [13]. Therefore, producing microporous carbons with pore size in the abovementioned range is an effective way to improve the supercapacitor capacitance. Polyvinylidene fluoride (PVDF) is usually used as the polymer precursor for preparing the electrodes of supercapacitors. PVDF is converted to microporous carbon by carbonization without other activation methods. The microporous carbon has high specific surface area and potential. It also possesses narrow micropore distribution characteristics [14-17]. Melamine is a nitrogen rich compound, which is easy to handle. It is usually used for doping nitrogen functional groups. Nitrogenenriched carbons possess high specific surface area and specific capacitance [18-21]. Nitrogen in melamine-derived carbons exists mainly in pyridinic, quaternary, and oxidized forms. The oxidized nitrogen is the most stable and the pyridinic nitrogen affects the electron donor-acceptor characteristics of the carbon materials, which leads to pseudocapacitive attraction between the protons of the electrolyte and the carbon electrode materials [22]. At a high carbonization temperature, more stable nitrogens are produced by the carbonization of melamine [23,24].

In this study, nitrogen-functionalized microporous carbons were prepared by an activation-free method using the PVDF/melamine mixture as the carbon precursor. The effect of carbonization temperature on the electrochemical performance of the PVDF/melaminebased electrode is discussed. 


\section{Experimental}

\subsection{Materials and preparation}

PVDF (Aldrich) and melamine (Aldrich) were used as the precursors for the nitrogen-functionalized microporous carbons. A mixture containing 1:0.5 ratio of the $\mathrm{PVDF} /$ melamine was put into a muffle furnace and was stabilized at $200^{\circ} \mathrm{C}$ in air for $2 \mathrm{~h}$. Then, carbonization was carried out at $700-900^{\circ} \mathrm{C}$ for $2 \mathrm{~h}$ in a tubular furnace under nitrogen gas with a heating rate of $5^{\circ} \mathrm{C} /$ $\mathrm{min}$ and a nitrogen flow rate of $200 \mathrm{~mL} / \mathrm{min}[6,25]$. The samples were named PVDF/melamine 700, 800 and 900, where 700 , 800 , and 900 represent the carbonization temperature.

\subsection{Measurements}

The surface characterization was performed by elemental analysis (EA). The textural characteristics of the PMs were analyzed at $77 \mathrm{~K}$ using a gas adsorption analyzer (BELSORP, BEL Japan). The specific surface areas and micropore volumes of the samples were determined from the Brunauer-Emmett-Teller (BET) and Dubinin-Radushkevich (D-R) equations. The electrochemical performance was characterized by cyclic voltammetry $(\mathrm{CV})$ and galvanostatic charge/discharge measurements using a three-electrode electrochemical cell. The threeelectrode cell consisted of a Pt wire as the counter electrode, $\mathrm{Ag} / \mathrm{AgCl}$ as the reference electrode, and $\mathrm{Ni}$ foam coated with the samples as the working electrode. The specific capacitances of the samples studied were estimated according to the following Eq. (1) [26,27]:

$$
C=\frac{1 \times \Delta t}{\Delta V \times m}
$$

where $C$ is the capacitance of the cell, $I$ the discharge current, $\Delta t$ the discharge time, $\Delta V$ the voltage range, and $m$ the mass of the active material on the electrode [28-30].

\section{Results and Discussion}

PVDF was used to obtain porous carbons by carbonization in the absence of an activation process. The specific surface area and pore volume of the samples studied were determined by nitrogen adsorption/desorption isotherms at $77 \mathrm{~K}$. The textural properties determined by the BET results are shown in Table 1. The decrease in the specific surface area of the samples studied is attributed to the effect of carbonization temperature. The total pore volume also decreased. Therefore, the formation of the micropores could be easily controlled by the carbonization process. However, the highest micropore volume was obtained at $800^{\circ} \mathrm{C}$. The PVDF/melamine 800 had the highest micropore volume $\left(0.2202 \mathrm{~cm}^{3} / \mathrm{g}\right)$ and the lowest mesopore volume $\left(0.1274 \mathrm{~cm}^{3} / \mathrm{g}\right)$, which is probably due to poor carbonization at the low temperature and the collapse of the micropores at the high temperature.

The surface characteristics of the samples studied were analyzed by EA. As shown in Table 1, the content of nitrogen groups on the PVDF/melamine 700, 800, and 900 are 14.9, 13.4, and $12.9 \%$, respectively. The nitrogen content decreased with the increasing carbonization temperature. The $\mathrm{PVDF} / \mathrm{melamine}$ 900 has the lowest nitrogen content $(12.9 \%)$, which is probably due to the volatilization of the N/C species at elevated carbonization temperatures [31].

Fig. 1 shows the $\mathrm{CV}$ of the samples studied using $6.0 \mathrm{M}$ po-

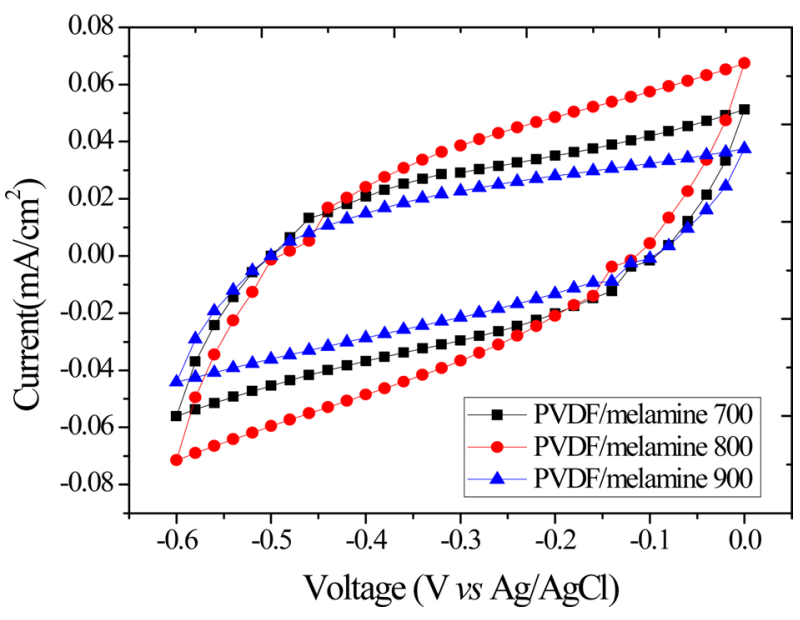

Fig. 1. Cyclic voltammetry of samples studied at $50 \mathrm{mV} / \mathrm{s}$. PVDF: polyvinylidene fluoride.

\section{Table 1. Chemical compositions and textural properties of the samples studied}

\begin{tabular}{|c|c|c|c|c|c|c|c|c|}
\hline & \multicolumn{5}{|c|}{ Textural properties } & \multicolumn{3}{|c|}{ Chemical compositions } \\
\hline & $\mathrm{S}_{\mathrm{BET}}{ }^{\mathrm{a}}$ & $V_{\text {total }}^{b}$ & $\mathrm{~V}_{\text {meso }}^{c)}$ & $\mathrm{V}_{\text {micro }}{ }^{\mathrm{d})}$ & $F_{\text {micro }}{ }^{e)}$ & $C^{f)}$ & $N^{g)}$ & $\mathrm{N} / \mathrm{C}^{\mathrm{h} /}$ \\
\hline $\mathrm{PVDF} /$ melamine 700 & 654 & 0.3514 & 0.1426 & 0.2088 & 59.42 & 75.40 & 14.89 & 0.1974 \\
\hline PVDF/melamine 800 & 638 & 0.3476 & 0.1274 & 0.2202 & 63.35 & 78.30 & 13.44 & 0.1717 \\
\hline PVDF/melamine 900 & 541 & 0.3027 & 0.1344 & 0.1683 & 55.60 & 78.68 & 12.87 & 0.1636 \\
\hline
\end{tabular}

BET: Brunauer-Emmett-Teller, PVDF: polyvinylidene fluoride.

${ }^{\text {a) }}$ Specific surface area $\left(\mathrm{m}^{2} \mathrm{~g}^{-1}\right)$.

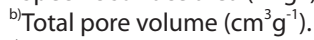

${ }^{c)}$ Mesopore volume $\left(\mathrm{cm}^{3} \mathrm{~g}^{-1}\right)$.

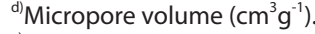

e)(Micropore volume/total pore volume) $\times 100(\%)$

${ }^{\text {f) }}$ Content of carbon (at\%).

${ }^{9}$ Content of nitrogen (at\%)

${ }^{\text {h) }}$ Content of nitrogen/content of carbon. 


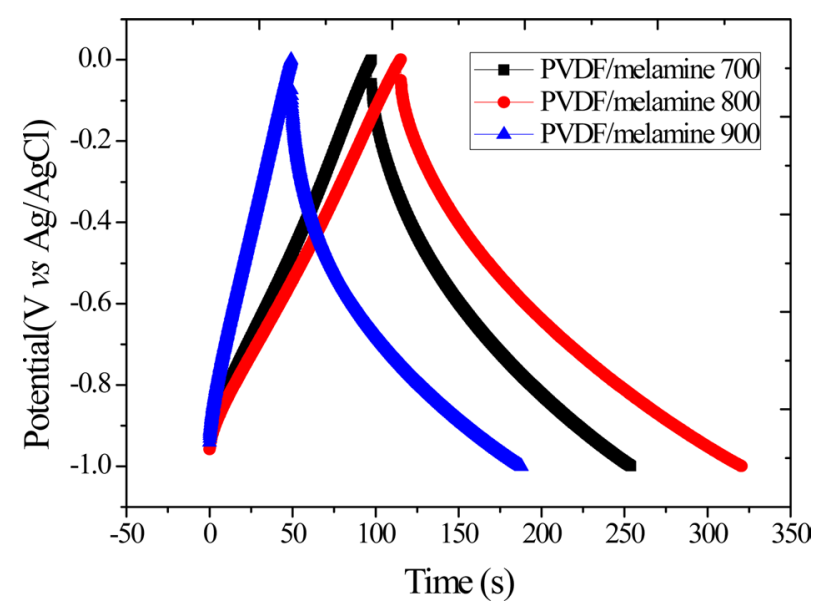

Fig. 2. Charge/discharge behavior of samples studied at $1 \mathrm{~A} / \mathrm{g}$. PVDF: polyvinylidene fluoride.

tassium hydroxide electrolyte solution at the scan rate $50 \mathrm{mV} / \mathrm{s}$ in the voltage range of $-0.6 \mathrm{~V}$ to $0.0 \mathrm{~V}$. The $\mathrm{CV}$ curves are symmetric rectangular in shape and exhibit a larger peak area, which shows that the sample has a high specific capacitance. The largest CV curve obtained was for the PVDF/melamine 800, which shows that it has a greater current density than the other samples studied, resulting from the micropore volume (Table 1).

Fig. 2 shows the galvanostatic charge/discharge curve at a loading current of $1 \mathrm{~A} / \mathrm{g}$. The galvanostatic charge/discharge curve is linear triangular in shape. The curve for the PVDF/ melamine 800 shows the largest peak and the longest discharge time. The specific capacitance is calculated from the discharge curve (Fig. 2); and it indicates 156, 205 and $139 \mathrm{~F} / \mathrm{g}$ on the $\mathrm{PVDF} /$ melamine 700, 800 and 900. The PVDF/melamine 800 exhibited the highest specific capacitance $(205 \mathrm{~F} / \mathrm{g})$. The specific capacitances of the samples studied are dependent on the carbonization temperature, which in turn can control the pore size of the carbon and the contents of the polar doping groups. The increase in capacitance is attributed to the added micropores. The nitrogen-doped microporous carbon exhibited enhanced electrochemical performance when prepared at the carbonization temperature of $800^{\circ} \mathrm{C}$, and demonstrated superior electrochemical supercapacitor and pseudocapacitive behaviors [32].

\section{Conclusions}

In this study, nitrogen-functionalized microporous carbons were prepared by carbonization of a PVDF/melamine mixture without an activation process. The nitrogen contents decreased with increasing carbonization temperatures. However, the micropore volume of the $\mathrm{PVDF} /$ melamine 800 was greater than that of the PVDF/melamine 700. The PVDF/melamine 800 sample had a maximum specific capacitance of $205 \mathrm{~F} / \mathrm{g}$ with a large micropore volume of $0.2202 \mathrm{~cm}^{3} / \mathrm{g}$. Thus, we found that the microporosity of the PVDF/melamine can be attributed to preparation at an optimum carbonization temperature, resulting in the easy transfer and excellent accessibility of the electrolyte ions in the nitrogen-functionalized carbon electrodes.

\section{Acknowlegments}

This research was supported by the Carbon Valley Project of the Korea Government (Ministry of Commerce, Industry and Energy) and Korea Ministry of Environment (MOE) as "GAIA Program".

\section{References}

[1] Inagaki M, Kang F, Toyoda M, Konno H. Carbon materials for electrochemical capacitors. In: Inagaki M, Kang F, Toyoda M Konno H, eds. Advanced Materials Science and Engineering of Carbon, Butterworth-Heinemann, Boston, MA, 237 (2014). http:// dx.doi.org/10.1016/B978-0-12-407789-8.00011-9.

[2] Frackowiak E, Béguin F. Carbon materials for the electrochemical storage of energy in capacitors. Carbon, 39, 937 (2001). http:// dx.doi.org/10.1016/S0008-6223(00)00183-4.

[3] Ma C, Song Y, Shi J, Zhang D, Zhai X, Zhong M, Guo Q, Liu L. Preparation and one-step activation of microporous carbon nanofibers for use as supercapacitor electrodes. Carbon, 51, 290 (2013). http://dx.doi.org/10.1016/j.carbon.2012.08.056.

[4] Chen XY, Chen C, Zhang ZJ, Xie DH, Deng X, Liu JW. Nitrogendoped porous carbon for supercapacitor with long-term electrochemical stability. J Power Sources, 230, 50 (2013). http://dx.doi. org/10.1016/j.jpowsour.2012.12.054.

[5] Qin CL, Lu X, Yin GP, Bai XD, Jin Z. Activated nitrogen-enriched carbon/carbon aerogel nanocomposites for supercapacitor applications. Trans Nonferrous Metals Soc China, 19, s738 (2009). http:// dx.doi.org/10.1016/S1003-6326(10)60142-2.

[6] Kim KS, Park SJ. Synthesis of nitrogen doped microporous carbons prepared by activation-free method and their high electrochemical performance. Electrochim Acta, 56, 10130 (2011). http:// dx.doi.org/10.1016/j.electacta.2011.08.107.

[7] Li W, Chen D, Li Z, Shi Y, Wan Y, Wang G, Jiang Z, Zhao D. Nitrogen-containing carbon spheres with very large uniform mesopores: the superior electrode materials for EDLC in organic electrolyte. Carbon, 45, 1757 (2007). http://dx.doi.org/10.1016/j. carbon.2007.05.004.

[8] Guo P, Gu Y, Lei Z, Cui Y, Zhao XS. Preparation of sucrose-based microporous carbons and their application as electrode materials for supercapacitors. Microporous Mesoporous Mater, 156, 176 (2012). http://dx.doi.org/10.1016/j.micromeso.2012.02.043.

[9] Kim KS, Park SJ. Synthesis and high electrochemical capacitance of $\mathrm{N}$-doped microporous carbon/carbon nanotubes for supercapacitor. J Electroanal Chem, 673, 58 (2012). http://dx.doi. org/10.1016/j.jelechem.2012.03.011.

[10] Hulicova D, Yamashita J, Soneda Y, Hatori H, Kodama M. Supercapacitors prepared from melamine-based carbon. Chem Mater 17, 1241 (2005). http://dx.doi.org/10.1021/cm049337g.

[11] Chen J, Jia C, Wan Z. Novel hybrid nanocomposite based on poly(3,4-ethylenedioxythiophene)/multiwalled carbon nanotubes/ graphene as electrode material for supercapacitor. Synth Met, 189, 69 (2014). http://dx.doi.org/10.1016/j.synthmet.2014.01.001.

[12] Ma C, Li Y, Shi J, Song Y, Liu L. High-performance supercapacitor electrodes based on porous flexible carbon nanofiber paper treated by surface chemical etching. Chem Eng J, 249, 216 (2014). http:// dx.doi.org/10.1016/j.cej.2014.03.083. 
[13] Kitajima M, Sato M, Nishide H. Preparation of flat porous carbon films from paper-thin wood shavings and control of their mechanical, electrical and magnetic properties. Carbon, 61, 260 (2013). http://dx.doi.org/10.1016/j.carbon.2013.05.003.

[14] Pan Y, Mei Z, Yang Z, Zhang W, Pei B, Yao H. Facile synthesis of mesoporous $\mathrm{MnO}_{2} / \mathrm{C}$ spheres for supercapacitor electrodes. Chem Eng J, 242, 397 (2014). http://dx.doi.org/10.1016/j. cej.2013.04.069.

[15] Lota G, Lota K, Frackowiak E. Nanotubes based composites rich in nitrogen for supercapacitor application. Electrochem Commun 9, 1828 (2007). http://dx.doi.org/10.1016/j.elecom.2007.04.015.

[16] Chen T, Dai L. Carbon nanomaterials for high-performance supercapacitors. Mater Today, 16, 272 (2013). http://dx.doi.org/ 10.1016/j.mattod.2013.07.002.

[17] Świetlik U, Grzyb B, Torchała K, Gryglewicz G, Machnikowski J. High temperature ammonia treatment of pitch particulates and fibers for nitrogen enriched microporous carbons. Fuel Process Technol, 119, 211 (2014). http://dx.doi.org/10.1016/j.fuproc. 2013.11.009.

[18] Su F, Zeng J, Yu Y, Lv L, Lee JY, Zhao XS. Template synthesis of microporous carbon for direct methanol fuel cell application. Carbon, 43, 2366 (2005). http://dx.doi.org/10.1016/j.carbon.2005.04.018.

[19] Leżańska M, Olejniczak A, Pacuła A, Szymański G, Włoch J. The influence of microporosity creation in highly mesoporous N-containing carbons obtained from chitosan on their catalytic and electrochemical properties. Catal Today, 227, 223 (2014). http://dx.doi. org/10.1016/j.cattod.2013.11.011.

[20] Lee SY, Park SJ. Carbon dioxide adsorption performance of ultramicroporous carbon derived from poly(vinylidene fluoride). J Anal Appl Pyrolysis, 106, 147 (2014). http://dx.doi.org/10.1016/j. jaap.2014.01.012.

[21] Zheng C, Zhou X, Cao H, Wang G, Liu Z. Synthesis of porous graphene/activated carbon composite with high packing density and large specific surface area for supercapacitor electrode material. J Power Sources, 258, 290 (2014). http://dx.doi.org/10.1016/j.jpowsour.2014.01.056.

[22] Chen XY, Xie DH, Chen C, Liu JW. High-performance supercapacitor based on nitrogen-doped porous carbon derived from zinc(II)bis(8-hydroxyquinoline) coordination polymer. J Colloid Interface Sci, 393, 241 (2013). http://dx.doi.org/10.1016/j.jcis.2012.10.024.

[23] Si W, Zhou J, Zhang S, Li S, Xing W, Zhuo S. Tunable N-doped or dual N, S-doped activated hydrothermal carbons derived from human hair and glucose for supercapacitor applications. Electrochim Acta, 107, 397 (2013). http://dx.doi.org/10.1016/j.electacta.2013.06.065.

[24] Im JS, Park SJ, Lee YS. Preparation and characteristics of electrospun activated carbon materials having meso- and macropores. $\mathrm{J}$ Colloid Interface Sci, 314, 32 (2007). http://dx.doi.org/10.1016/j. jeis.2007.05.033.

[25] Khairnar V, Jaybhaye S, Hu CC, Afre R, Soga T, Sharon M, Sharon M. Development of supercapacitors using porous carbon materials synthesized from plant derived precursors. Carbon Lett, 9, 188 (2008).

[26] Xu B, Hou S, Zhang F, Cao G, Chu M, Yang Y. Nitrogen-doped mesoporous carbon derived from biopolymer as electrode material for supercapacitors. J Electroanal Chem, 712, 146 (2014). http:// dx.doi.org/10.1016/j.jelechem.2013.11.020.

[27] Mehmani A, Prodanović M. The effect of microporosity on transport properties in porous media. Adv Water Resour, 63, 104 (2014). http://dx.doi.org/10.1016/j.advwatres.2013.10.009.

[28] Chen A, Liu C, Yu Y, Hu Y, Lv H, Zhang Y, Shen S, Zhang J. A co-confined carbonization approach to aligned nitrogen-doped mesoporous carbon nanofibers and its application as an adsorbent. J Hazard Mater, 276, 192 (2014). http://dx.doi.org/10.1016/j. jhazmat.2014.05.045.

[29] Guo Z, Zhou Q, Wu Z, Zhang Z, Zhang W, Zhang Y, Li L, Cao Z, Wang H, Gao Y. Nitrogen-doped carbon based on peptides of hair as electrode materials for surpercapacitors. Electrochim Acta, 113, 620 (2013). http://dx.doi.org/10.1016/j.electacta.2013.09.112.

[30] Leżańska M, Olejniczak A, Pacuła A, Szymański G, Włoch J. The influence of microporosity creation in highly mesoporous $\mathrm{N}$-containing carbons obtained from chitosan on their catalytic and electrochemical properties. Catal Today, 227, 223 (2014). http://dx.doi. org/10.1016/j.cattod.2013.11.011.

[31] Del Regno A, Siperstein FR. Organic molecules of intrinsic microporosity: characterization of novel microporous materials. Microporous Mesoporous Mater, 176, 55 (2013). http://dx.doi. org/10.1016/j.micromeso.2013.03.041.

[32] Prasad KPS, Dhawale DS, Joseph S, Anand C, Wahab MA, Mano A, Sathish CI, Balasubramanian VV, Sivakumar T, Vinu A. Postsynthetic functionalization of mesoporous carbon electrodes with copper oxide nanoparticles for supercapacitor application. Microporous Mesoporous Mater, 172, 77 (2013). http://dx.doi. org/10.1016/j.micromeso.2013.01.023. 